\title{
Erratum
}

Hurter, S. J. \& Pollack, H. N. (1994) Effect of the Cretaceous Serra Geral igneous event on the temperatures and heat flow of the Paraná Basin, southern Brazil.

Basin Res., 7, 239-244.
Unfortunately, the final version of this paper was printed without the authors' corrections. The corrected paper is reprinted here in full. The publishers would like to apologise to the authors for the inconvenience caused.

\section{Effect of the Cretaceous Serra Geral igneous event on the temperatures and heat flow of the Paraná Basin, southern Brazil}

\author{
Suzanne J. Hurter* and Henry N. Pollack $\dagger$ \\ * Institute of Astronomy and Geophysics, University of \\ São Paula, CP 9638, São Paulo SP, Brazil \\ $\dagger$ Department of Geological Sciences, The University of \\ Michigan, Ann Arbor, MI 48109-1063, USA
}

\begin{abstract}
We investigate the effects of the cooling of intrusive and extrusive igneous bodies on the temperature history and surface heat flow of the Paraná Basin. The Serra Geral igneous event (130-135 Ma) covered most of this basin with flood basalts. Associated with this event numerous sills and dykes intruded the sediments and basement, and extensive underplating may have occurred in the lower crust and upper mantle beneath the basin. We develop an analytical model of the conductive cooling of tabular intrusive bodies and use it to calculate temperatures within the sediments as a function of time since emplacement. Depending on the thickness of these igneous bodies and the timing of sequential emplacement, the thermal history of a given locus in the basin can range from a simple extended period of higher temperatures to multiple episodes of peak temperatures separated by cooling intervals. The cooling of surface flood basalts, sills and dykes is capable of maintaining temperatures above the normal geothermal gradient temperatures for a few hundred thousand years, while large-scale underplating may influence temperatures for up to 10 million years. We conclude that any residual heat from the cooling of the Serra Geral igneous rocks has long since decayed to insignificant values and that present-day temperatures and heat flow are not affected. However, the burial of the sediments beneath the thick basalt cap caused a permanent temperature increase of up to $50^{\circ} \mathrm{C}$ in the underlying sediments since the beginning of the Cretaceous.
\end{abstract}

\section{INTRODUCTION}

The region covered by the Paraná Basin contains a great volume of igneous rocks associated with the Cretaceous Serra Geral flood basalt event. Furthermore, this large magmatic event occurred within a narrow time interval, making it one of the most spectacular igneous events in Earth history. Assuming that the extruded igneous rocks may represent only a fraction of the total amount of melt generated during this event, it is possible that a large volume of the melt intruded and underplated the sediments and crystalline crust. In this paper we address the influence of the solidification and cooling of such a volume of magma upon the temperatures and heat flow in the Paraná Basin over time. We develop an analytical solution to the heat conduction equation that yields temperature as a function of time due to sill-like intrusions or extrusive flows on to the surface. First we assess the temperature perturbation due to the cooling of flood basalt and sills intruded into the sediments, and then we estimate the thermal effects of a large underplate beneath the basin.

At the present-day, heat flow in the Paraná Basin ranges from 40 to $75 \mathrm{~mW} \mathrm{~m}^{-2}$ (Hurter, 1992). Lower and 
more uniform values are found in the central part of the basin whereas the eastern margin has higher and more variable heat flow. The mean $( \pm S D$ ) heat flow for 56 sites within the basin is $56 \pm 11 \mathrm{~mW} \mathrm{~m}^{-2}$ with geothermal gradients ranging from 20 to $30 \mathrm{~K} \mathrm{~km}^{-1}$, such that the temperature within the sediments varies from $20^{\circ} \mathrm{C}$ close to the surface to about $150^{\circ} \mathrm{C}$ at $5 \mathrm{~km}$ depth (Hurter, 1992).

\section{THE SERRA GERAL IGNEOUS EVENT}

\section{Intrusions, extrusions and underplating}

The Serra Geral igneous event at 130-135 Ma (Rocha Campos et al,, 1988) resulted in the extrusion of voluminous flood basalts and pervasive dyke and sill intrusion into the sediments and basement of the Paraná Basin. The present-day extent of these basalt flows is of the order of $10^{6} \mathrm{~km}^{2}$, and the thickest flood basalt accumulation is about $1.7 \mathrm{~km}$. A stacking of about 20 flows is reported by Ernesto \& Pacca (1988). Sill intrusions occur in the entire basin, with an average individual thickness of $10-20 \mathrm{~m}$, but exceeding hundreds of metres in some cases (Melfi et al., 1988). The cumulative sill thickness may comprise up to $30 \%$ of the total stratigraphic column (Zalán et al., 1991). Vertical profiles of basalt flows have yielded essentially contemporaneous K-Ar dates (Rocha Campos et al., 1988). Palaeomagnetic studies of lava flows indicate that up to $1 \mathrm{~km}$ of basalt could have piled up in $1 \mathrm{Ma}$ or less (Ernesto \& Pacca, 1988). This is supported by a recent study including ${ }^{40} \mathrm{Ar} /{ }^{39} \mathrm{Ar}$ age determinations dating the initiation of volcanism in the southern part of the basin at $133 \pm 1 \mathrm{Ma}$, lasting for less than $1 \mathrm{Ma}$ (Renne et al., 1992).

White \& McKenzie (1989) argue that large volumes of melt can be generated under lithosphere in extension, by adiabatic decompression of rising mantle material, a situation that may precede continental rifting. Only a fraction of the melt produced by decompression is extruded at the surface. White (1989) estimates that perhaps the total volume of igneous rocks emplaced could be a factor of two to three greater than the extruded portion. On the basis of model calculations, a $10-15 \mathrm{~km}$ layer of underplated material could be generated and emplaced within $5 \mathrm{Myr}$ (Furlong \& Fountain, 1986). Molina et al. (1989), in modelling and interpreting gravity anomalies in the northern Parana Basin, suggest that the extrusion of flood basalt may have been accompanied by underplating and that the mafic material that did not ascend to the surface may have solidified in the lower $10-20 \mathrm{~km}$ of the crust, intruding the lower crust and underplating it with high-density mafic material.

To summarize, the Serra Geral igneous event at 130-135 Ma extruded a great volume of flood basalts rapidly. The associated intrusive bodies (dykes and sills) are clearly related to the flood basalts, and their intrusion is practically simultaneous to the extrusion event. Figure 1 shows a hypothetical crustal section depicting the various kinds of igneous bodies associated with this event, including the possible existence of a large underplate.

\section{THEORY OF MULTIPLE INTRUSIONS/EXTRUSIONS}

Here we develop the theoretical analysis to calculate the temperature history of the sediments due to the extrusion of basalt flows at the surface and the intrusion of sills in the subsurface. We have derived an analytical heat conduction model that allows temperatures as a function of depth and time to be calculated at any time after intrusion of multiple sills, arbitrarily distributed throughout the sedimentary column. As sills are by definition laterally extensive compared with their thickness, and the heat lost due to cooling is principally in the vertical direction, it is reasonable to use a onedimensional model in which sills are represcnted by horizontally infinite slabs, bounded on top and bottom by parallel planes. The temperature as a function of depth and time since intrusion of a single sill can be obtained through the analytical solution to the one-dimensional time-dependent heat conduction equation with no sources or sinks:

$$
\frac{\partial^{2} T}{\partial z^{2}}-\frac{1}{\alpha} \frac{\partial T}{\partial t}=0
$$

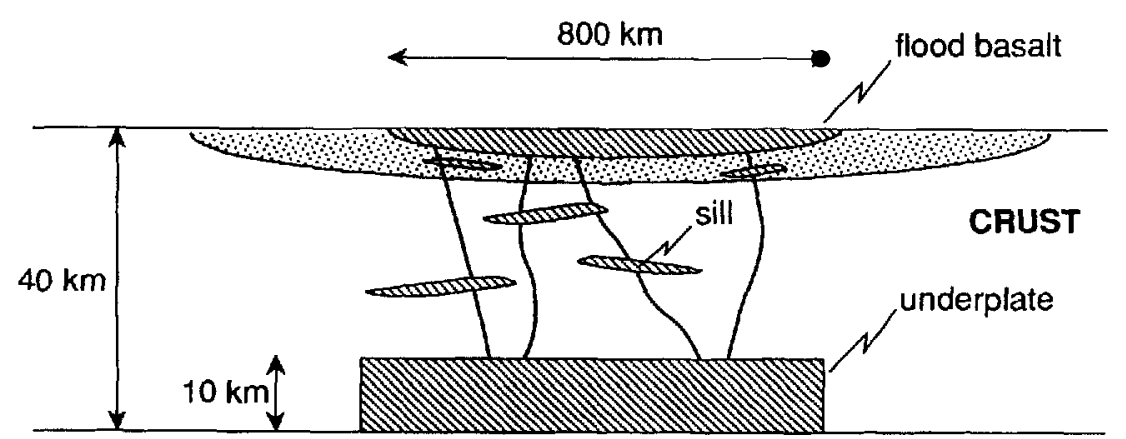

pre-volcanic sediments igneous rocks
MANTLE

Fig. 1. Schematic crustal cross-section of the Parana Basin (modified from Molina et al., 1989) showing sills, dykes and possible underplate. 


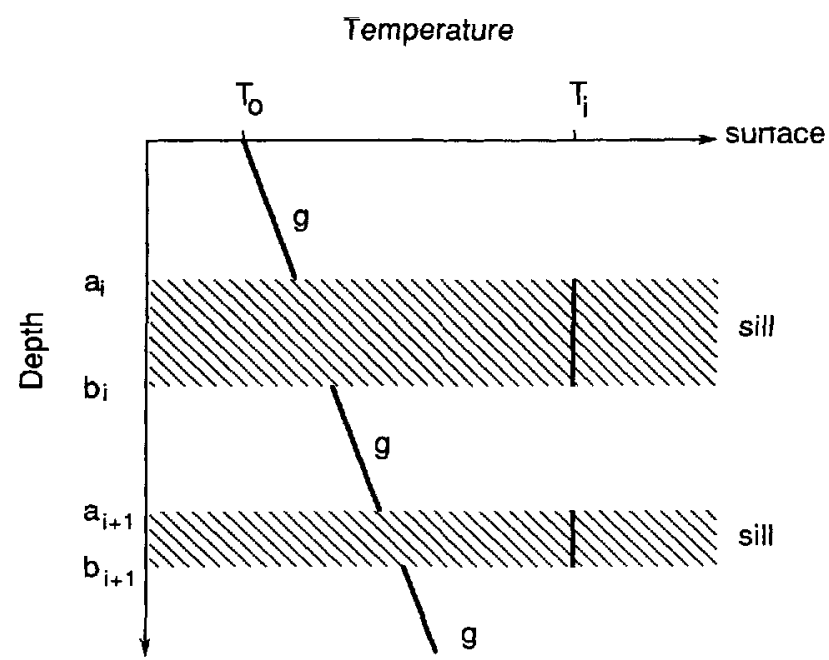

Fig. 2. Initial conditions for the analytical model of multiple intrusions. The bold line shows temperatures at $t=0$. $T_{0}$ is the surface temperature, $T_{\mathrm{i}}$ the intrusion temperature, $g$ the average geothermal gradient. The shaded rectangles represent sills with top at depth $a_{i}$ and bottom at depth $b_{i}$.

For a sill with top at depth $z=a$ and bottom at $z=b$, intruding at a temperature $T_{i}$ within a semi-infinite medium with geothermal gradient $g$ and thermal diffusivity $\alpha$, and bounded at the surface $z=0$ with surface temperature $T_{0}$, appropriate initial and boundary conditions are (Fig. 2):

$$
\begin{array}{lll}
T=T_{\mathrm{i}} & a<z<b & t=0, \\
T=T_{0}+g z & 0<z<a \text { and } z>b & t=0, \\
T=T_{0} & z=0 & t>0 .
\end{array}
$$

The initial condition given by Eq. (2b) describes the sedimentary strata and intrusives at their post-intrusive stratigraphic positions, and with the temperatures in the sediments determined by the geothermal gradient evaluated at post-intrusive depths. This initial condition ignores the vertical displacement of the temperature field in the sediments caused by the physical insertion of the intrusives into the sediments, but the errors introduced into the post-intrusive thermal history are insignificant for all situations addressed in this investigation.

Equation (1), under the conditions in Eq. (2), was solved using the method of images and direct integration of the expression found in Carslaw \& Jaeger $(1959, \mathrm{p}$. 62). The solution is expressed by:

$$
\begin{aligned}
T(a, b, z, t)= & \frac{1}{2}\left(T_{\mathrm{i}}-T_{0}\right)\left\{\operatorname{erf}\left(\frac{z-a}{\beta}\right)-\operatorname{erf}\left(\frac{z-b}{\beta}\right)\right. \\
& \left.+\operatorname{erf}\left(\frac{z+a}{\beta}\right)-\operatorname{erf}\left(\frac{z+b}{\beta}\right)\right\} \\
& -\frac{1}{2} g z\left\{\operatorname{erf}\left(\frac{z-a}{\beta}\right)-\operatorname{erf}\left(\frac{z-b}{\beta}\right)\right. \\
& \left.-\operatorname{erf}\left(\frac{z+a}{\beta}\right)+\operatorname{erf}\left(\frac{z+b}{\beta}\right)\right\}
\end{aligned}
$$

$$
\begin{aligned}
& +\frac{\beta g}{2 \sqrt{\pi}}\left\{\exp \left(-\frac{(b-z)^{2}}{\beta^{2}}\right)\right. \\
& -\exp \left(-\frac{(b+z)^{2}}{\beta^{2}}\right) \\
& \left.-\exp \left(-\frac{(a-z)^{2}}{\beta^{2}}\right)+\exp \left(-\frac{(a+z)^{2}}{\beta^{2}}\right)\right\}
\end{aligned}
$$

where erf is the error function, $\beta=(4 \alpha t)^{1 / 2}$ and $T(a, b, z, t)$ is the resulting temperature perturbation due to a single sill. The solution for the simultaneous intrusion of $n$ sills (see Fig. 2) of different thicknesses $\left(b_{i}-a_{i}\right)$ is obtained by superposing the solutions of each individual sill, such that

$T(z, t)=T_{0}+g z+\sum_{i=1}^{n} T\left(a_{i}, b_{i}, z, t\right)$.

In the numerical evaluation of this solution, rock thermal diffusivity is assumed to be $10^{-6} \mathrm{~m}^{2} \mathrm{~s}^{-1}$, uniform throughout. The thermal diffusivity of common rocks varies by about a factor of two. This range of diffusivity causes no significant difference in the temperature increment due to the intrusion, only a time lag of a few thousand years in the attainment of the same temperatures. The heat transferred from the intrusion into the surrounding rocks comprises heat lost through cooling from the intrusion temperature to background geothermal gradient temperature, plus the latent heat of crystallization. Latent heat release was simulated with an appropriately higher intrusion temperature (Jaeger, 1965). In our computations we use $T_{i}=1200^{\circ} \mathrm{C}$.

\section{EFFECTS OF COOLING BASALT FLOWS AND UPPER CRUSTAL SILL INTRUSIONS}

Intrusion of an individual sill releases an amount of heat proportional to its thickness. Subsequently, the thermal diffusivity of the surrounding rocks controls the rate of conductive heat transfer, and any location within a range equivalent to a few sill thicknesses will experience an increase in temperature up to some maximum value roughly inversely proportional to the distance of the point of interest to the intrusive body. The temperature at that point will then decrease gradually until the background geothermal gradient temperature is reestablished.

The temperature history for a site affected by simultaneous multiple intrusions can be much more complex than the case discussed above. On the one hand, sills at different relative distances to a given location may cause the site to experience several increases and falls of temperature as the 'thermal front' emanating from each sill reaches it. On the other hand, the composite effect of multiple sill intrusions to the thermal history of a site may be a single extended period 
of high temperatures as the thermal front of each sill reaches the site before the previous front has had time to dissipate fully.

We have evaluated Eq. (4) for several distributions of flows and sills, but report here only one representative example depicted in Fig. 3, a calculation performed on a stratigraphic section of $2 \mathrm{~km}$ containing $900 \mathrm{~m}$ of surface basalt flow and 10 sills with thicknesses varying between 1 and $12 \mathrm{~m}$. We assumed a surface temperature $T_{0}=20^{\circ} \mathrm{C}$ and a geothermal gradient of $26 \mathrm{~K} \mathrm{~km}^{-1}$, the average for the Parana Basin (Hurter, 1992). Figure 3 illustrates the thermal history of the complete igneous / sedimentary column at different times between $1 \mathrm{yr}$ and $200 \mathrm{kyr}$ after the igneous event. Each curve corresponds to the temperature as a function of depth, at indicated times after intrusion. One year after intrusion (Fig. 3a), the thermal signature of individual sills can be clearly rccognized as high-temperature spikes; the broad high-temperature depth interval at the top of the section represents the thick surficial basalt cap. Peak sediment temperatures within the sill-intruded depth interval (1.8-2.2 $\mathrm{km}$ depth) range from the intrusion temperature immediately adjacent to the sills to $170^{\circ} \mathrm{C}$ away from the sills, and are reached within $1 \mathrm{yr}$ to $300 \mathrm{yr}$ after sill intrusion. The 100 -yr curve shows that peak temperatures at sill sites decrease rapidly and heat is transferred to the sediments in the vicinity of these sills, smoothing out the spikes. The effect of the surficial basalt cap is not yet felt at the depth of the sills. Temperatures at $4 \mathrm{kyr}$ in the $1.8-2.2 \mathrm{~km}$ depth interval range from 118 to $125^{\circ} \mathrm{C}$ and are rather uniform. Temperaures do not fall below $100^{\circ} \mathrm{C}$ before the thermal front from the overlying basalt cap reaches this interval sometime around $5 \mathrm{kyr}$; by $6 \mathrm{kyr}$ the entire section is again warming. The later thermal history can be observed in Fig. 3(b), depicting an expanded view of the sediment/sill interval between 1.8 and $2.2 \mathrm{~km}$ depth only. The 15-kyr curve in Fig. 3(b) shows heating still in progress; the heating continues up to $27 \mathrm{kyr}$ at which time the shallower part of the depth interval of interest ( $1.8 \mathrm{~km}$ depth) starts to cool while the deeper part $(2.2 \mathrm{~km})$ is still undergoing warming. Maximum temperatures reached at this second warming range from 185 to $210^{\circ} \mathrm{C}$ in this section and at $30 \mathrm{kyr}$ the whole interval has practically uniform temperatures of $180-190^{\circ} \mathrm{C}$. Thereafter, this section cools uniformly but slowly, and at $100 \mathrm{kyr}$ temperatures are still above $100^{\circ} \mathrm{C}$; it takes $180 \mathrm{kyr}$ for the whole section to fall below $100^{\circ} \mathrm{C}$. Only within $200 \mathrm{kyr}$ is the section within $20^{\circ} \mathrm{C}$ of the geothermal gradient background temperatures.

The effect of the surface basalt cap extruded as a sequence of thin $(50 \mathrm{~m})$ flows at a rate of 1 flow $/ 50 \mathrm{kyr}$, rather than as a single $900 \mathrm{~m}$ extrusion, is negligible, with each flow decaying to background temperatures within $30 \mathrm{kyr}$, before the next flow extrudes. Only when the extrusion of the total surficial basalt thickness occurs simultaneously with the sill intrusions at depth, as depicted in Fig. 3, does the basalt cover provide a second heating event which maintains temperatures within the sediments above $100^{\circ} \mathrm{C}$ for about $150 \mathrm{kyr}$. The sequential emplacement of the sills and flows, i.e. distributing the intrusion and extrusion events over time, allows the loss of heat and the reduction of temperatures during the intervals between the emplacement of individual basalt flows / sill intrusions. By considering the sills intruded simultaneously with the extrusion of the flood basalts, their combined effect is maximized. The modelling of sequential sill intrusion is complicated by the fact that the sequence at which they might have been emplaced is

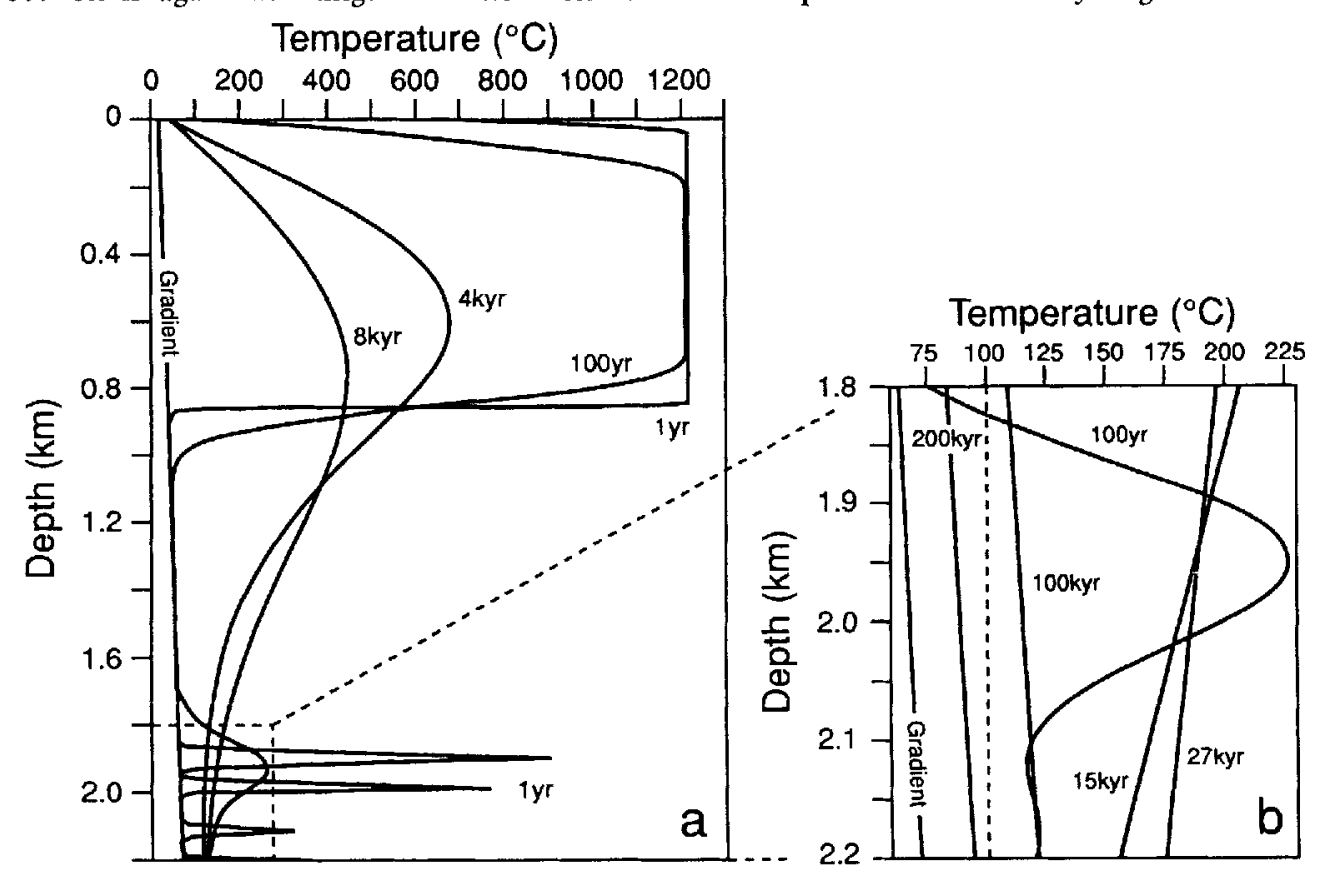

Fig. 3. (a) Calculated temperature evolution due to multiple sill intrusion and simultaneous basalt cap extrusion. Each curve is labelled with the respective time after extrusion/intrusion. (b) Expanded view of the intruded interval for later times; 100-yr curve is shown in both (a) and (b). The temperature due to a geothermal gradient of $26 \mathrm{~K} \mathrm{~km}^{-1}$ is also shown. 
unknown. Nevertheless, the example above uses reasonable ranges in thickness and timing and reveals how short-lived the effects of basalt flows and sill intrusion are.

To illustrate further these results and the general characteristics of this short-lived event, we have evaluated $\mathrm{Eq}$. (3) for the instantaneous extrusion of $2 \mathrm{~km}$ of basalt, more than twice the thickness of the flow considered in the previous calculations and depicted in Fig. 3. Peak temperatures at $5 \mathrm{~km}$ depth (Fig. 4a) are higher (more than $200^{\circ} \mathrm{C}$ above background temperatures), but short-lived, decaying to a perturbation of less than $50^{\circ} \mathrm{C}$ within $500 \mathrm{kyr}$. The temperature perturbation decays to less than $1 \%$ of the unperturbed temperatures within $8 \mathrm{Myr}$ after the extrusion event at all depths between the surface and $5 \mathrm{~km}$ depth in the basin. This maximum effect scenario (instantaneous thick extrusion) is, however, unlikely, and we believe that the cooling of flood basalts and upper crustal sill-like intrusions is likely to be completed within less than $1 \mathrm{Myr}$. There certainly will not be a residual perturbation to the present-day temperatures within the sediments.
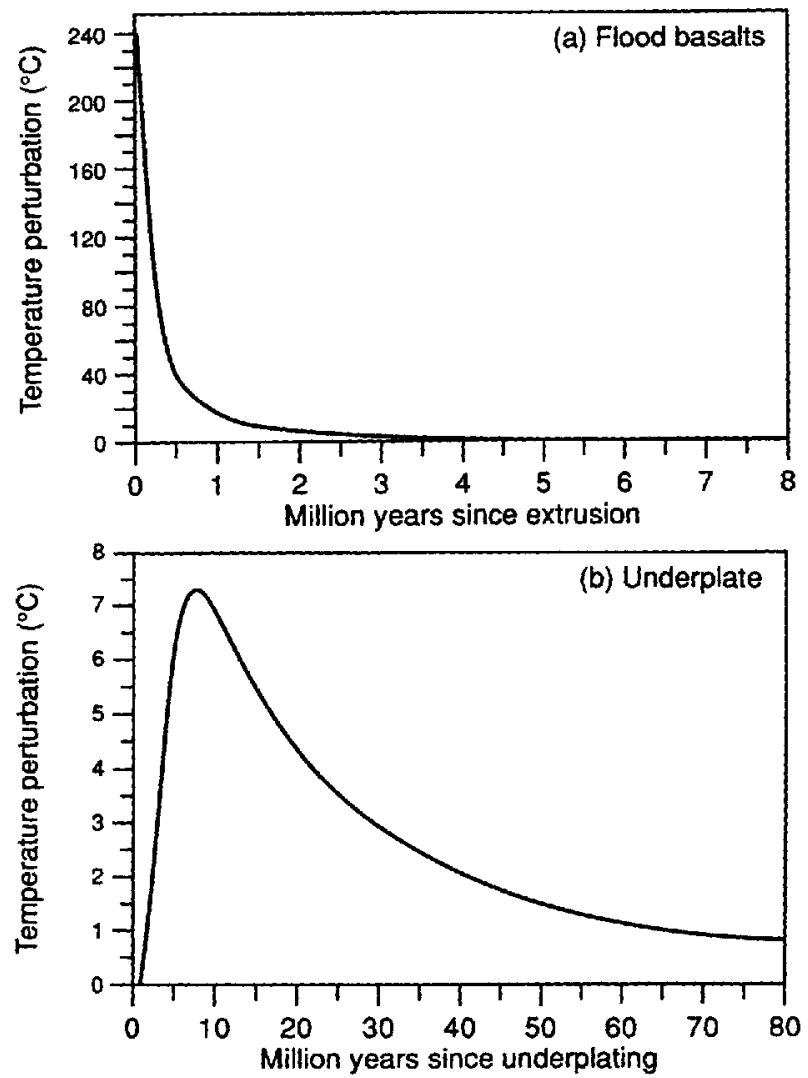

Fig. 4. Temperature perturbation at $5 \mathrm{~km}$ depth due to (a) cooling of $2-\mathrm{km}$-thick surface flood basalts and (b) cooling of a $10-\mathrm{km}$-thick underplate with upper surface at a depth of $30 \mathrm{~km}$ in the lower crust. The thermal perturbation amounts to less than $1 \%$ of the undisturbed temperatures after $8 \mathrm{Myr}$ since flood basalt extrusion and after $80 \mathrm{Myr}$ following the underplating event. Note the different amplitude and time scales of (a) and (b): the perturbation shown due to the basalt flow decays completely well before the effect of the underplate reaches its maximum.

\section{EFFECTS OF AN UNDERPLATE}

The magnitude and duration of a thermal perturbation at $5 \mathrm{~km}$ depth due to the cooling of an underplate in the lower crust between 30 and $40 \mathrm{~km}$ depth (Fig. 1) can also be evaluated with Eq. (3). The 10-km-thick underplate corresponds to a volume more than five times that of the extruded basalt volume. We use the same values for all other parameters as in the calculations for the flood basalt extrusion. The perturbed temperatures will decay to less than $1 \%$ of the unperturbed temperatures in the basin within $80 \mathrm{Myr}$ after the underplating event (Fig. $4 \mathrm{~b}$ ). The magnitude of the temperature perturbation is much less than in the previous case; the maximum perturbation is less than $10^{\circ} \mathrm{C}$, causing an added heat flow at the surface of less than $5 \mathrm{~mW} \mathrm{~m}^{-2}$, for only a short interval soon after emplacement.

\section{DISCUSSION AND CONCLUSION}

The analytical model we present of the conductive cooling of intrusive sill-like bodies and extrusive basalt flows suggests that these affect the temperature field within the sediments of the Parana Basin for less than $1 \mathrm{Myr}$, and that the temperatures above $100^{\circ} \mathrm{C}$ can be maintained only for about $200 \mathrm{kyr}$ locally. The duration of maximum temperature conditions is a function of the time interval between extrusion/intrusion of individual flows/sills. The effects on basin temperatures and heat flow due to a large underplate in the lower crust beneath the basin reach a maximum of about $10^{\circ} \mathrm{C}$ and $5 \mathrm{~mW} \mathrm{~m}^{-2}$, respectively, at about $10 \mathrm{Myr}$ after the underplating event, decaying to unperturbed values within $80 \mathrm{Myr}$. Therefore, transit effects due to the cooling of a lower crust underplate do not affect the present-day heat flow and temperature field in the Paraná Basin.

The thermal perturbation in the mantle that led to the production of the basalt and underplate has an even smaller direct effect on the thermal history of the basin. Most estimates of the 'excess' temperature in the mantle that leads to significant volumes of melt are in the range 200-300 K (Schilling, 1991; Sleep, 1992). A perturbation of this magnitude, while very significant in terms of igneous rock production, plays an insignificant role in the thermal evolution of the basin sediments. The increase of heat flow into the basin is both small and transient, and does not come close to equalling the long-term thermal effects of burying the sediments beneath the flood basalt cap, as discussed briefly below.

Thermal perturbations and their duration in sedimentary basins are of interest for assessing the maturity of the sediments and the state of evolution of hydrocarbons. For that purpose the important parameter is the time-temperature index (TTI), i.e. an index that quantifies the cumulative effects of both temperature conditions and their duration. The burial of sediments 
beneath a thick basalt cap increase the temperatures under the basalt for long periods of time, not because of the transient elevated temperatures of the extrusion, but rather because of the effects of the geothermal gradient and the depression of the sediments to greater depths. The deposition of $2 \mathrm{~km}$ of basalt in the central part of the Paraná Basin could cause a temperature increase on the order of $50^{\circ} \mathrm{C}$ in the sediments, assuming an average geothermal gradient. This temperature increase is larger than that due to the cooling of a large underplate and less than temperature increases due to shallow intrusive and extrusive bodies. However, because the time interval in which this temperature increase has existed is at least an order of magnitude longer (more than $100 \mathrm{Myr}$ ) than that given by the cooling of igneous bodies, the burial effect is larger than that yielded by the igneous event. On a regional scale, burial by basalt flows affects maturation and hydrocarbon generation more than the cooling of igneous bodies.

In conclusion, it is unlikely that there are residual effects related to the cooling of the Serra Geral igneous rocks (flood basalt, intrusives and underplate) in the present-day heat flow and temperature field of the Paraná Basin. In terms of promoting the organic maturation of the sediments and hydrocarbon generation on a regional scale, burial depth beneath the thick flood basalts may be the most important factor.

\section{ACKNOWLEDGEMENTS}

This work was supported by the Fundação de Amparo à Pesquisa do Estado de São Paulo (FAPESP), proc. no. 1063/87. Discussions with Fernando B. Ribeiro during the development of the theory and reviews by Stephen Hallinan and an unidentified referee are gratefully acknowledged.

\section{REFERENCES}

Carsi.aW, H. S. \& Jakgl:k, J. C (1959) Conduction of Heat in Solids, 2nd edn. Oxford University Press.

Ernfsio, M. \& Pacca, I. G. (1988) Paleomagnetism of the Paraná basin flood volcanism, southern Brazil. In: The Mesozoic Flood Volcanism of the Parana Basin: Petrogenesis and Geophysical Aspects (Ed. by E. M. Piccirillo \& A. J. Melfi), pp. 229-255. Instituto Astronômico e Geofisico, University of São Paulo, Brazil.
Furlong, K. P. \& Founjain, D. M. (1986) Continentalcrustal underplating: thermal considerations and seismicpetrologic consequences. 7. Geophys. Res., 91(B8), 82858294.

HurTer, S. J. (1992) Heat fiow, thermal structure and thermal evolution of the Paraná Basin, southern Brazil. PhD thesis, The University of Michigan.

JAFGER, J. C. (1965) Application of the theory of heat conduction to geothermal measurements. In: Terrestrial Heat Flow (Ed. by W. H. K. Lee), Am. Geophys. Un. Geophys. Mon, 6, 7-23.

McKkn/JF, D. \& Bick1.F, M. J. (1988) The volume and composition of melt generated by extension of the lithosphere. 7. Petrol., 29, 625-679.

Mellit, A. J., Piccirul. Io, E. M. \& NAridY, A. J. R. (1988) Gcological and magmatic aspects of the Paraná Basin - an introduction. In: The Mesozoic Flood Volcanism of the Paraná Basin: Petrogenesis and Geophysical Aspects (Ed. by E. M. Piccirillo \& A. J. Melfi), pp. 1-13. Instituto Astronômico e Geofisico, University of São Paulo, Brazil.

Molina, E. C., Ussami, N., Sá, N. C. dF \& Burl\%kow, D. (1989) Interpretaçăo dos dados gravimétricos da parte norte da Bacia do Paraná. Rev. Bras. Geoc, 19, 187-196.

Ri:nni, P. R., ERnesto, M., Paccia, I. G., Col, R. S., Guin, J. M., Privor, M. \& Plirrin, M. (1992) The age of Paraná flood volcanism, rifting of Gondwanaland, and the JurassicCretaceous boundary. Science, 258, 975-979.

Rocila Campos, A. C., Corbani, U. G., Kawashita, K., SONOKI, H. M. \& Sonoki, I. K. (1988) Age of the Parana flood volcanism. In: The Mesozoic Fiond Volcanism of the Paraná Basin: Petrogenesis and Geophysical Aspects (Ed. by E. M. Piccirillo \& A. J. Melfi), pp. 25-45. Instituto Astronômico e Geofisico, University of São Paulo, Brazil.

Schil.ing, J.-G. (1991) Fluxes and excess temperatures of mantle plumes inferred from their interaction with migrating mid-ocean ridges. Nature, 352, 397-403.

St.ikp, N. H. (1992) Hotspot volcanism and mantle plumes. Ann. Rev. Earth planet, Sci., 20, 19-43.

WHTT:, R. S. (1989) Volcanism and igneous underplating in sedimentary basins and at rifted continental margins. In: Origin and Evolution of Sedimentary Basins and Their Energy and Mineral Resources (Ed. by R. A. Price), Am. Geophys. Un. Geophys. Mon., 48, 125-127.

WirTTl, R. S. \& MCKIN\%/r; D. (1989) Magmatism at rift zones: the generation of volcanic continental margins and flood basalts. J. Geophys. Res., 94, 7685-7730.

Zai.án, P. V., Wolle, S., Astolle, M. A., Vilria, I. S., Concriçäo, J. C., Appt, V. T., Nito, E. V. S., Clirquilra, J. R. \& Marquis, A. (1991) The Paraná Basin, Brazil. In: Interior Cratonic Basins (Ed. by M. W. Leighton, D. R. Kolata, D. F. Olts \& J. J. Eidel), $A A P G$ Memoir, 51, 681-708.

Received 7 December 1993; revision accepted 19 August 1994. 